\title{
Brain death and its cognitive significance
}

\author{
Ahmadreza Hemati Moghadam ${ }^{1}$, Hadi Samadi ${ }^{1}$, Maryam Katoozi ${ }^{*}$ \\ 1. Assistant Professor of Philosophy, Faculty of Law, Theology and Political Science, Science and Research Branch, Islamic Azad Univer- \\ sity Tehran, Iran \\ 2. PhD Student of Philosophy of Science, Faculty of Law, Theology and Political Science, Science and Research Branch, Islamic Azad \\ University Tehran, Iran
}

Recieved: 15 Jun. 2019

Revised: . 17 Jul. 2020

Accepted: 17 Jul. 2020

\section{Keywords \\ Death \\ Brain death}

Psychological awareness

Cognitive activities

Corresponding author

Maryam Katoozi, PhD Student of Philosophy of Science, Faculty of Law, Theology and Political Science, Science and Research Branch, Islamic Azad University Tehran, Iran

Email: Baharkatuzi@gmail.com

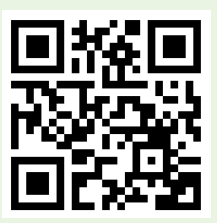

\section{Abstract}

Every human being always tried to define death to reach a solution to life, maybe forever. He always faced with such questions: what is death? When can we say somebody died? We have two main approaches in medicine to define death: Cardiopulmonary death, which means the irreversible cessation of the cardiopulmonary system (heart and lungs), and brain death which means the irreversible cessation of brain functions. The second approach promoted by way of using ventilators, which could revive brain death Patients. So brain functions became the most important criterion to define death. Now the question is: if the irreversible cessation of cognitive activities in the brain is the criterion to define death or the irreversible cessation of the cardiopulmonary system? Moreover, if we choose the first, which property or function can be the criterion to define cognitive activity? According to this study's findings, it is concluded that the irreversible cessation of cognitive activities in the brain is the criterion to define death. Accordingly, human beings are trying to find a reason why awareness is the right criterion to define cognitive activity.

Citation: Hemati Moghadam A, Samadi H, Katoozi M. Brain death and its cognitive significance. Advances in Cognitive Sciences. 2020;22(1):93-101. 
(A)

\author{
تاملاتى درباره مرك مغزى بر اساس تغييرات شناختى \\ احمدرضا همتى مقدم'، هادى صمدى'، مريم كاتوزى آث

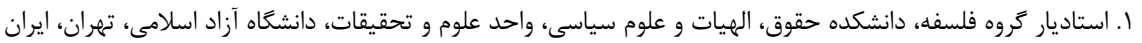

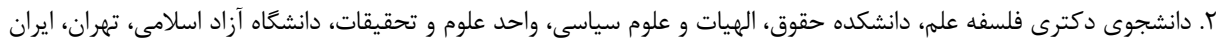

انسان به دنبال تعريفى از مرك بوده تا راه كارهايى براى حفظ بقا بيابد. او با انواع سؤالات مانند مرك جيست؟ جه زمانى دريافت: اصلاح نهايى:

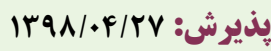
واثهناى كليدى مى توانيم بكوييم مرگ اتفاق افتاده است؟ مواجه بوده است. دو رويكرد درباره تعريف مرك در بزشكى، رويكرد قلبى_ريوى مرى مغزى به معناى توقف بدون بازگشت جريان خون و تنفس و رويكرد مرك مغزى است كه به معناى از دست دادن بدون بازگشت كاركرد مغز تعريف مى شود. رويكرد دوم با به وجود آمدن احياكنندهها مد نظر قرار ترفت. يس كاركردهاى مغزى مهممترين معيار جهت تعريف مرى در نظر كرفته شده و قطع يا عدم قطع عملكرد آنها ملاك تميز زندگى از مرك شد. آيا روند بدون بازگشت فعاليتهاى شناختى در مغز ملاك تعيين مرك است، يا روند قطع مراكز مربوط به تنفس و ضربان قلب و اكر روند بدون بازگشت فعاليتهاى شناختى ملاك تعيين مرك باشد، كدام ويزَى يا كاركردى مىتواند ملاك مشخص فعاليت شناختى باشد؟ در اين مقاله استدلال مىشود كه روند بدون بازگشت فعاليتهاى شناختى ملاك تعيين مرى مغز است و 》آكاهى" مى تواند ملاك دقيق ترى براى انجام فعاليت شناختى باشد.

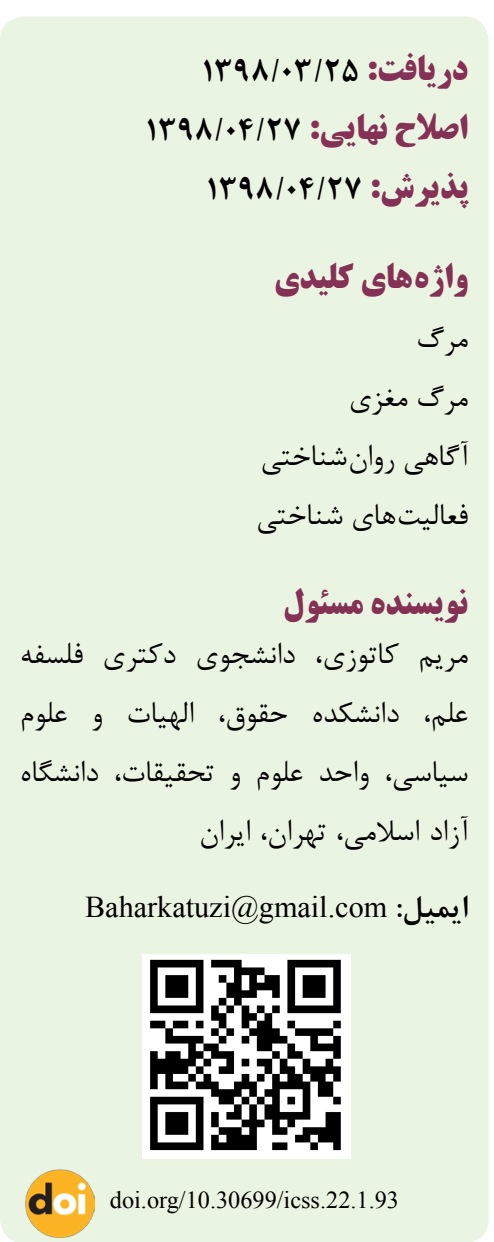

مقلدمه

بوده است ( (1). در حذشته مرگ امرى اسرارآميز، ترسناك، قطعى و غير قابل مداخله شناخته مى شد اما در عصر جديد و باظهور تكنولوزىهاى متعدد مقوله مرگ نيز از تاثيرات زندگى مدرن دور نمانده و به نظر

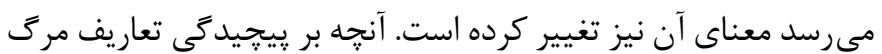
افزوده، امكاناتى است كه از يس بيشرفت تكنولوزى براى احياى بيماران
مرى شايد يِيجيدهترين مقولهاى است كه بشر، در كنار ماهيت و تعريف خداوند و جَكونكى ييدايش هستى، براى ارائه تعريفى از آن، انواع مسيرها را رفته است و اهميت آن بدان جهت است كه رابطه مستقيم با ميل به بقا، يعنى مهممترين روياى بشر دارد. در تاريخ تفكر بشر، از ابتدا تا به امروز، همواره ارائه تعريف دقيقى از مرگ با مشكلات فراوانى مواجه 
و ادامه عملكرد قلب و ريه ها و با حفظ كردش خون در بدن، بيمار را تا زمان اتصال به دستگًاه زنده نكَه مى دارند. همين امر، موجب به به وجود آمدن معيار و تعريف جديدى دربارهٔ مرك شد كه تحت عنوان

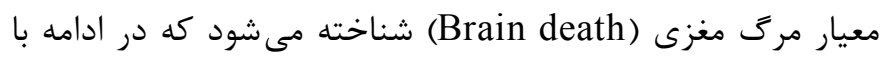
اختصار BD از آن نام برده خواهد شد.

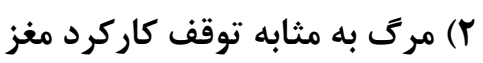

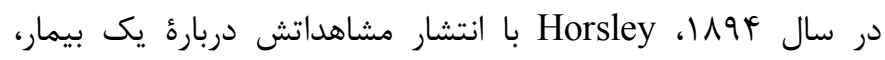
نمونهاى را توصيف كرد كه اكنون مىتوان آن را اولين بيمار مرى مغزى لقب داد (ז). از يس اين نمونه، اين تعريف برآمد كه كاهى يك آنى

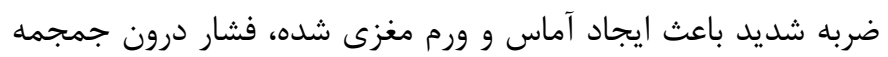

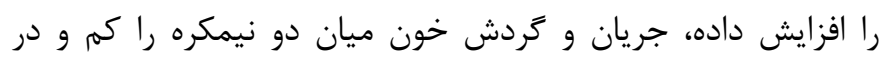
نهايت قطع كرده و سبب نابودى كامل مغز مى شود. در نهايت در سرد سال

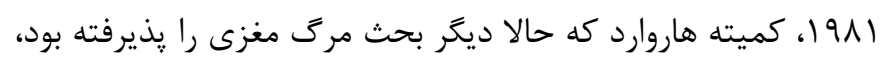

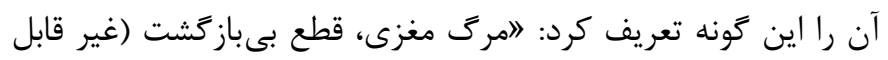

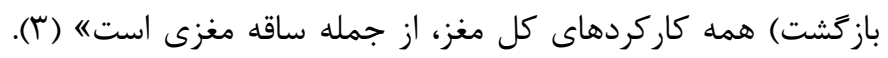

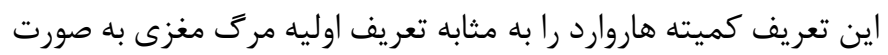

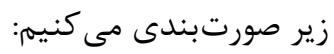

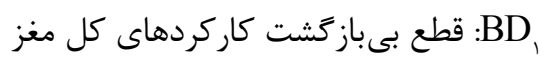

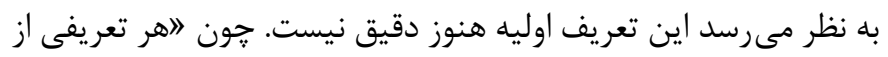

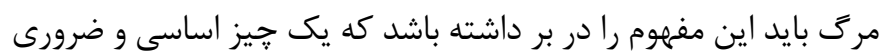
(Fundamental and essential)

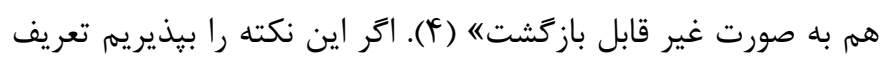
بالا را بايد به صورت زير تغيير داد:

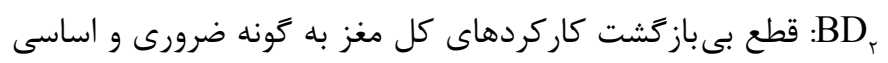
به نظر مىرسد مفاهيم ضرورى و اساسى بيجيد تعريف مى افزايد. زمانى كه اين دو وازه وارد تعريف شوند، ما نيازمند

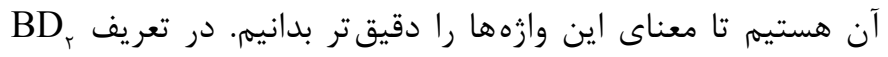

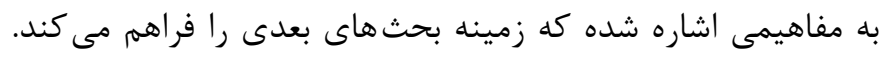

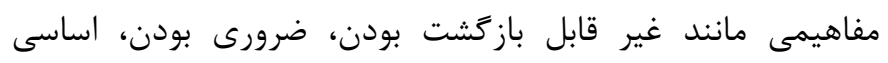
بودن، كاركردهاى مغز يا كاركردهاى حياتى مغز، و مفهوم كل مغزئ.

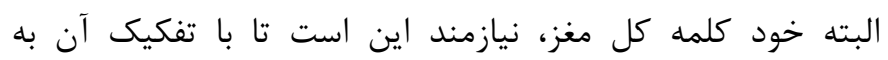
بخشهاى ساقه مغز و بخش بالايى يا كورتكس مغز، موقعيت و

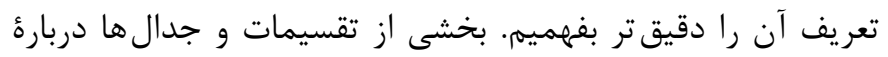
بحث مرك مغزى مربوط به اين است كه اين وازهها و مفاهيم را

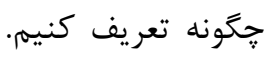
به نظر مىرسد مفهوم كاركردهاى ضرورى و اساسى را مىتوان به
و براى به تاخير انداختن مرگ به كار گرفته شد. اين امكانات امكان ادامه حيات افراد رو به مرى را افزايش دادند و در نتيجه تشخيص مركى

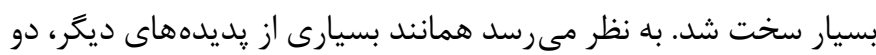

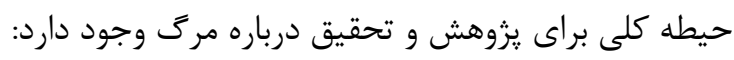

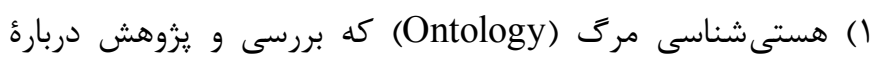

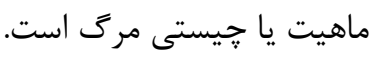

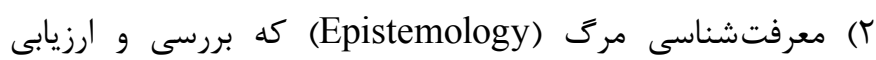

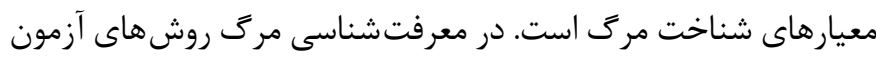
و تشخيص مرك بررسى مى شوند.

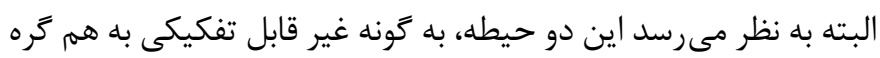

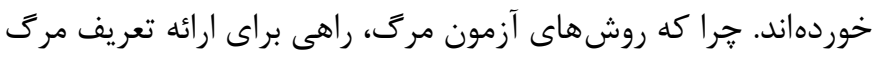

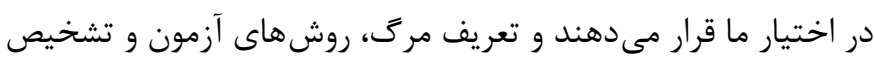

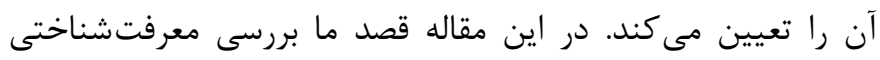

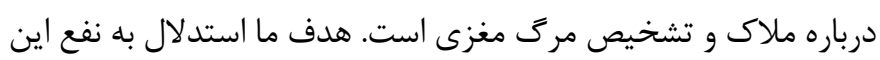

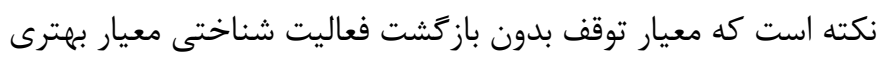

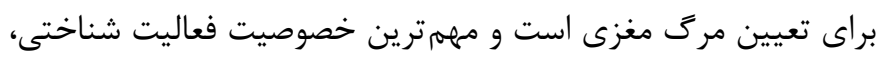

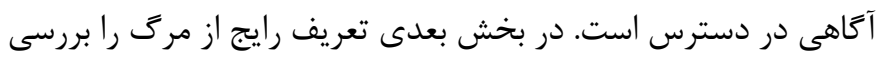
كرده و در بخشهاى بعد به بررسى تعريف مرى مغزى و و ملاك آن آن

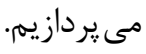

\section{()) مرى قلبى_ريوى (Cardiopulmonary death)} تا نيمه قرن بيستم، معيار قلبى_ريوى، يعنى قطع جريان تنفس فرئ

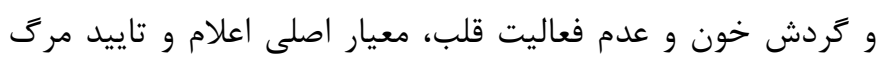

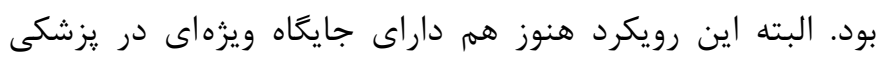

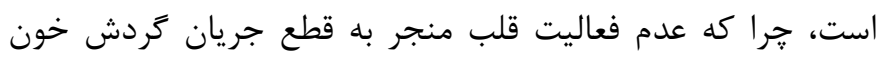
شده و به تبع آن عدم تنفس و از كار افتادن فعاليت ريوى را به إنهان دنبال خواهد داشت. بديهى است اين اتفاق در نبود دستخاه هاى احياكننده، باعث مرى مى شود. به نظر مى رسد معيار قلبى_ريوى، همواره معيارى موفق و قابل اتكا باشد جون قطع تنفس و قطع نطع

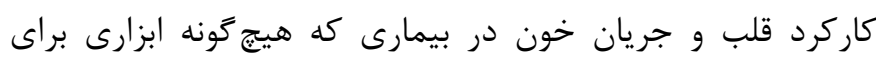

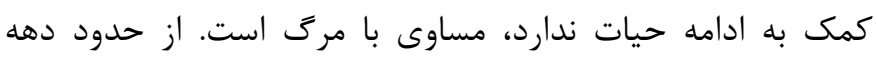

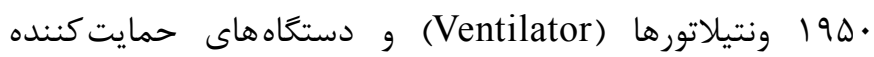
حيات براى نجات بيماران استفاده شدند. اولين ونتيلاتور در سال

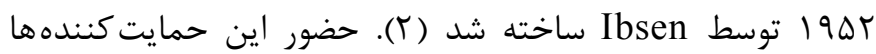
باعث شد تا آرام آرام در دهه هفتاد ميلادى تغييرات بنيادى دربارهٔ معيار مرى رخ دهد و معيار مرى مغزى نيز به مثابه رقيبى براى معيار قلبى_ريوى معرفى شد. اين دستكاههاى كمك كننده با حفظ دماري 


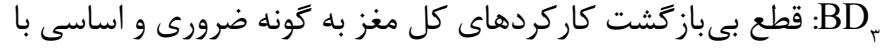
در نظر ترفتن امكانات و تكنولوزى روز (a) به نظر مىرسد اين تعريف مى تواند مرك را به امرى نسبى تبديل كند

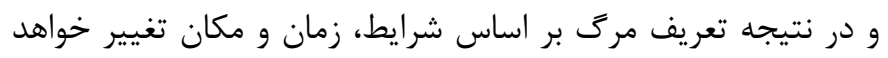
كرد. مثلا دو بيمار با شرايط مشابه، كه يكى مثلا در خاورميانه يا آفريقا

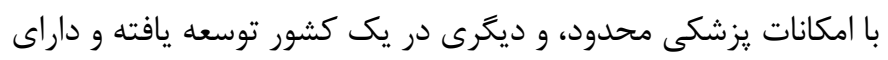

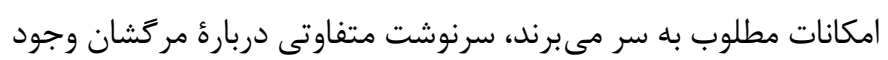
دارد. بدين ترتيب بيمارى كه در مركزى با امكانات محدود قرار دارد

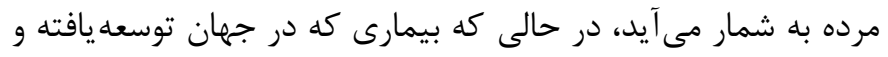

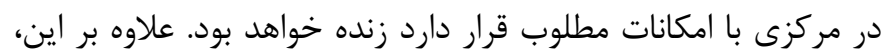
تعريف بالا باعث مى شود مرك در بستر زمان تعريف شود. مثلا بيمارى

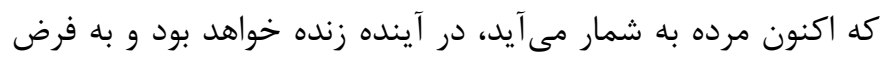

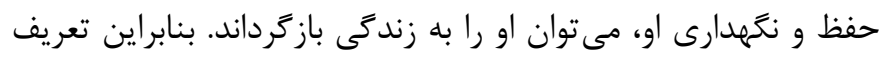

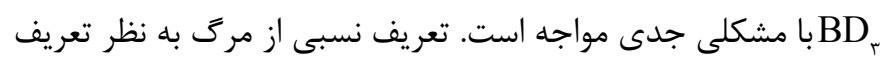

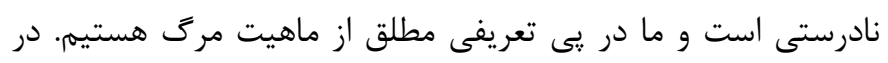

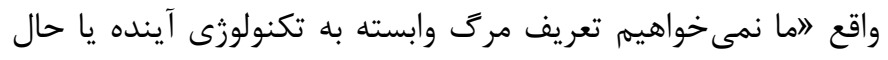

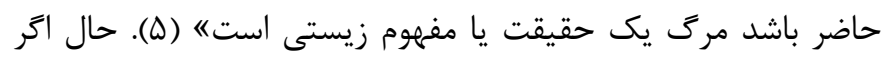

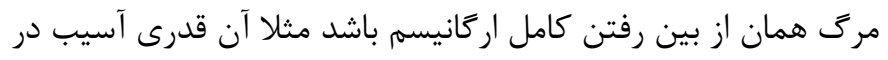
مغز به وجود آمده باشد كه امكان باز خشت به حالت اوليه و سلامت تحت هيج شرايطى وجود نداشته باشد، يا به كلام ديكر مغز در واقع از بين

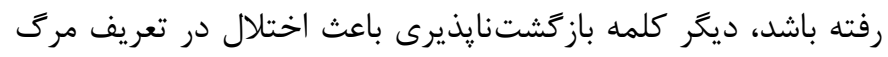

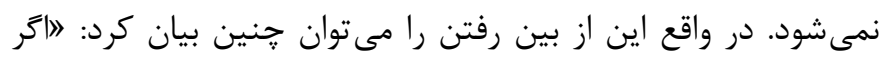

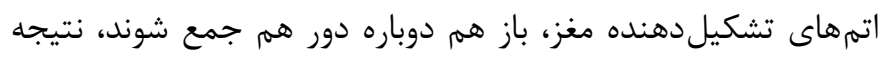

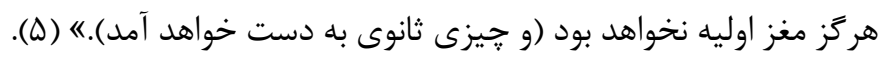

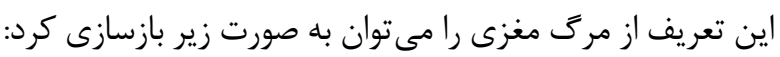

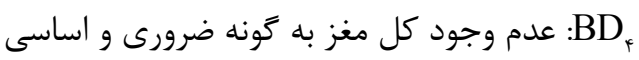

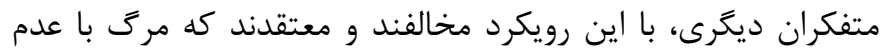

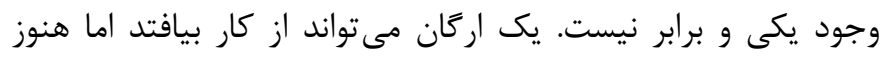
وجود داشته باشد، درست مانند موتورى كه از كار افتاده اما وجود دارد.

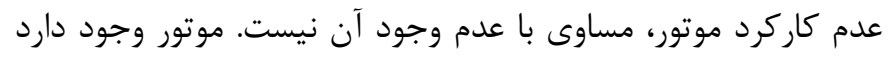

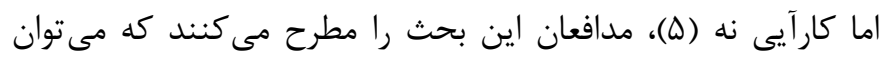

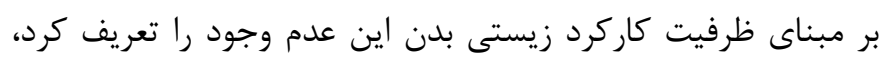

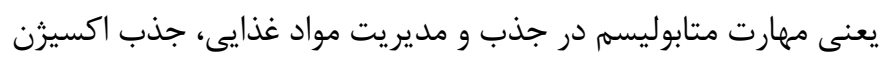

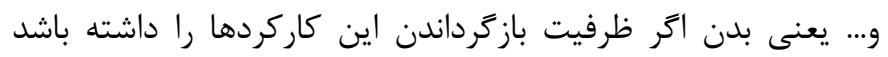

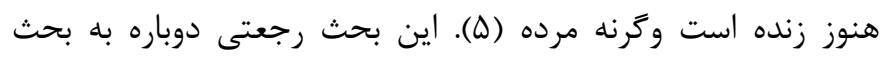

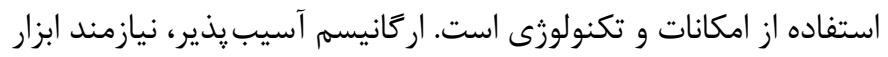
و امكاناتى است كه كمك كند تا اين ظرفيت و كاركرد حفظ شود.

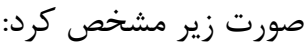
كاركردهاى ضرورى و اساسى: كاركردهايى هستند كه وجود آنهان آنها منجر

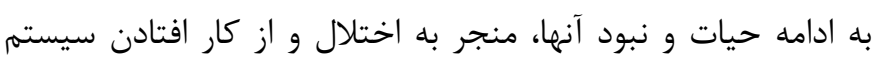

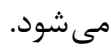
اما درباره مفهوم "غير قابل بازَشت بودن" بحث گستردهتر است.

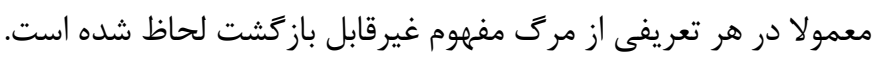

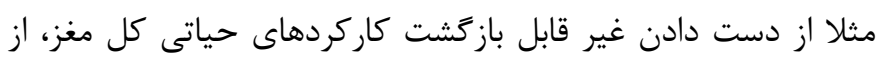
دست دادن غير قابل بازگشت كاركردهاى قلبى_ريوى و نظاير آن.

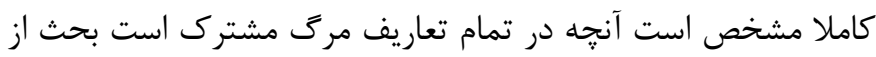

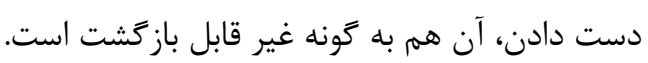

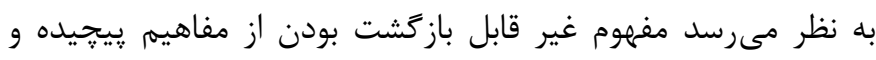

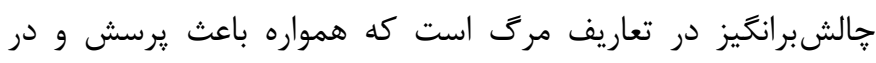

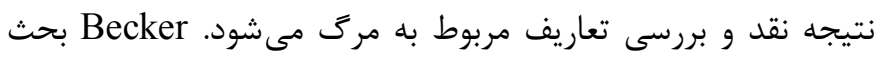

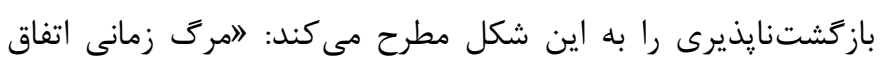

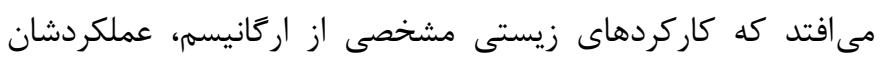

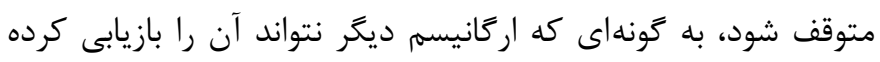

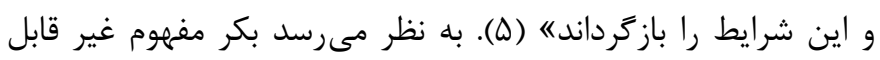

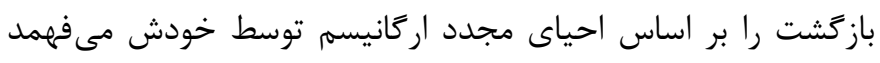
(Self-restarting)

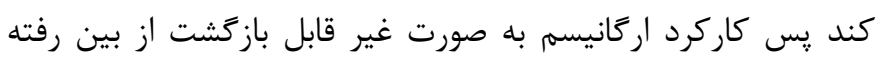

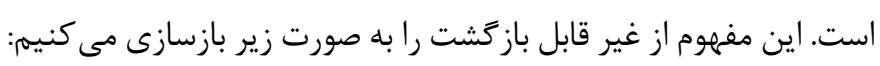

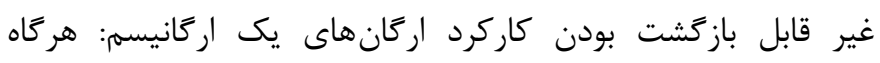

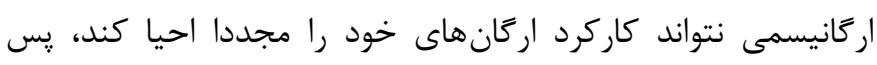

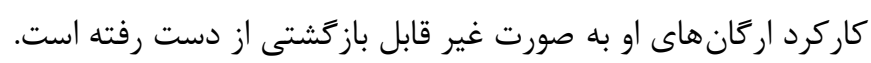

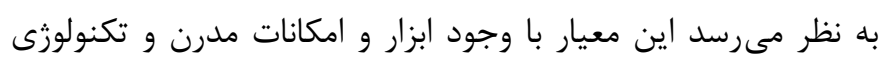

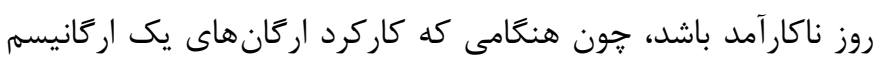

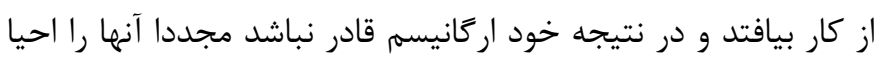

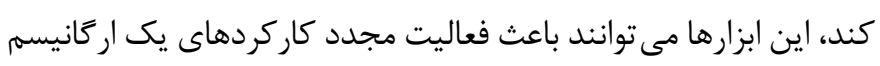

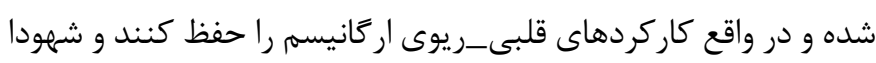

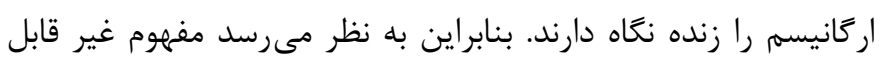
باز خشت را بايد بازبينى كرد:

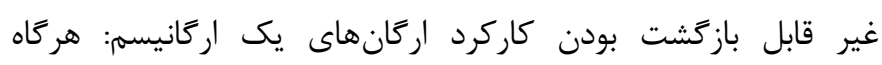

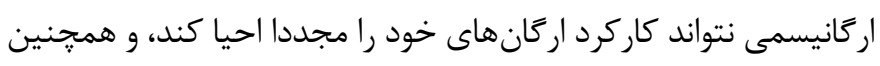

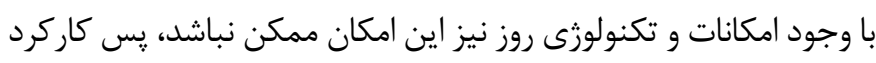

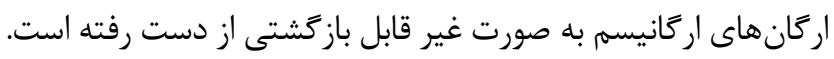

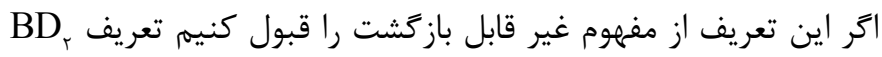
را بايد به صورت زير تغيير داد: 
يكديكر و با مغز و البته توسط مغز را در بر دارد، كه در نهايت كليت منسجم و يكيار קه موجود زنده را مىسازد. پٍ در واقع كل بودن و يكيارجخى، ويزَىى اى نيست كه بتواند توسط تك تك اعضا كسب شده

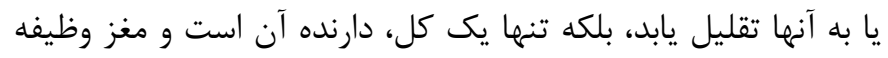

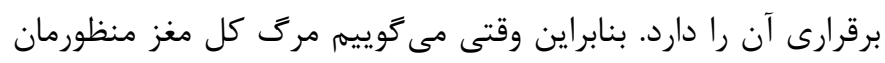

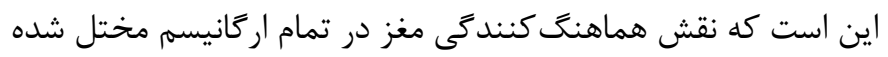

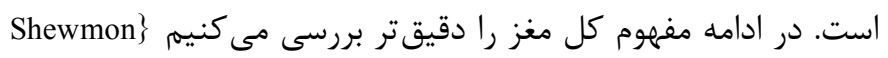
مخالف اين ادعا است. او مى نويسد: المغز هم مانند اعضاى ديكر، يكى از عضوهاى بدن

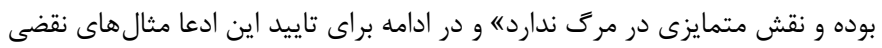

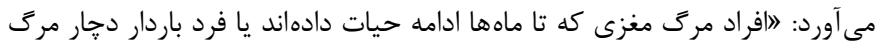
مغزى كه توانسته جنين را از هفته لا ات كب زبنده نكَه دارد... جطور اين بدن اكر مرده

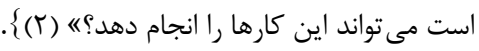

\section{(Whole brain death) مرك كل مغز} در بخش قبل تعريف اوليه از مرك مغزى را به معز صورت زير صورتبندى

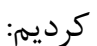
BD مغز انسان شامل قسمتهاى متنوعى است كه هر كدام در عين ارتباط

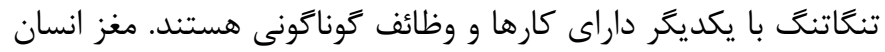
از ديد ساختار، هماند مغز ديخر يستانداران است ولى كورتكس آن در مقايسه با ديخر يستانداران داراى گسترش و پِيشرفت بسيار بيشترى

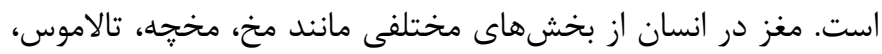
هييوتالاموس، يل مغزى، بطنهاى مغز، ساقه مغز تشكيل شده است إن.

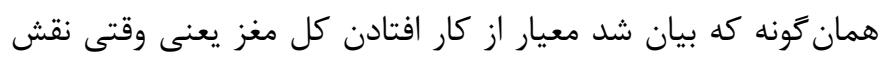

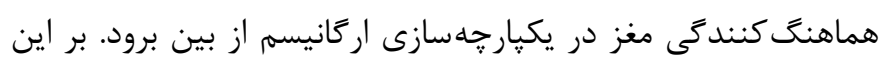
اساس تعريف اوليه از مرى را بايد به صورت زير بازسازى كرد:

(BD*, Bernat تعريف بالا را دقيقتر مى كند و مىنويسد: اقطع يا از دست دادن غير قابل بازگشت كاركردهاى مههم و حياتى كه سبب از دست

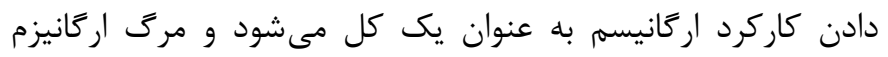
را سبب مى شوده (أ). در اين رويكرد، زمانى مركى اتفاق مى افتد

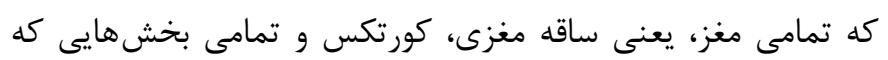

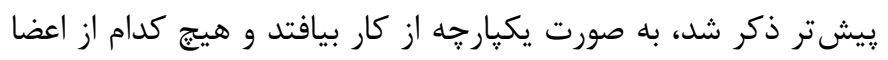

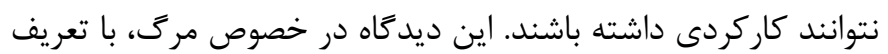
اور كانيزمى از مرگ مرتبط است هرا كه در تعريف اركانيزمى از مرك،

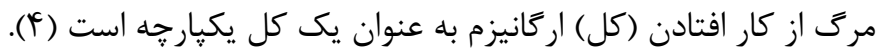
تعريف اركانيسميك درباره مرى را مىتوان به صورت زير مشخص كرد:
بنابراين مجددا در دام تكنولوزى و تعاريف نسبى اسير خواهيم شد. به نظر مىرسد كلمه غير قابل بازگشت بودن يا عدم بازگشت يذيرى،

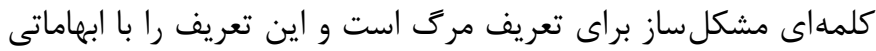
بع ياسخ مواجه مىسازد. بدين ترتيب برخى بر اين باورند كه مفهوم

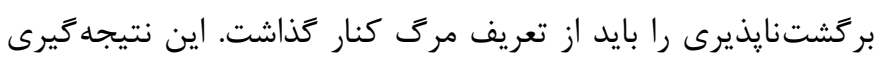

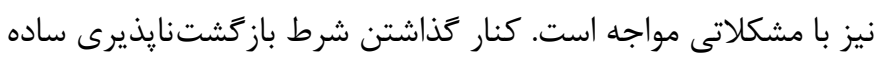
نيست. درست است كه تعاريف نمى خواهند در قيد امكانات و تكنولوزى بنى

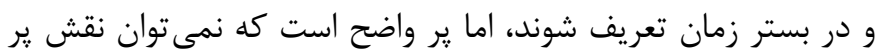
رنگ اين امكانات و تغييراتى را كه به معناى مرك دادهاند انكار كرد. ״س همجنان به نظر مىرسد نياز است مفهوم بازگشتنايذيرى به طور

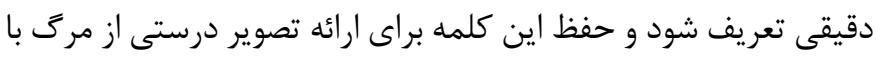
توجه به وجود امكانات لازم باشد \}ييش از ادامه بحث لازم به توضيح است كه له اساسا مى توان مركَ را مانند هر يديده ديكرى، يا يك رويداد تلقى كرد و يا يك يروسه. يروسه بودن مستلزم آن است كه مسيرى طى شده و با شروع از الف، و طى كردن ب، ج، دو ... به ن ختم شود. اما رويداد در يك لحظه زمانى تعريف شده و اتفاقات

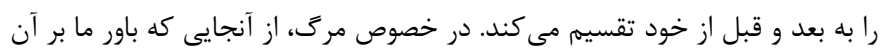
است كه مرك، در معنا و شكل دقيق خود، در يك لحظه به طور كامل و نهايى اتفاق افتاده و فرد را از موقعيت زنده بودن، به موقعيت مردن و عدم حيات، انتقال مى دهد، يس مرى را يك رويداد مى دانيم. جرا كه در صورتى كه مرك را رويداد ندانيم، بايست جيزى ميان زنده بودن و مرك تعريف كنيه، يروسهاى كه در آن مركَ اتفاق مى افتد، يروسهاى كه نه زندكى است و نه مرك و فردى كه در آن قرار دارد، نه زنده است و نه

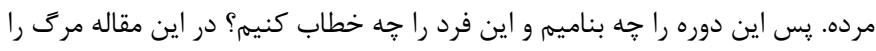
به مثابه يك رويداد در نظر كرفتهام و بر اين اساس به بحث و بررسى آن مى يردازمجا.

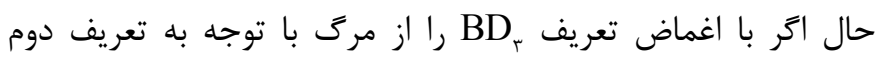

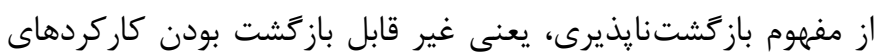
اوركانيزم، بيذيريم با مفهوم ديخرى روبروييم كه نيازمند توضيح و بائي تدقيق است. مفهوم كل مغز. زمانى كه در بحث مرك، از كلمه كل حرف به ميان آمده بايد فهميد منظور از اين كل جيست. آيا كل در اينجا به معناى تجمع تمام اعضاى دهاى

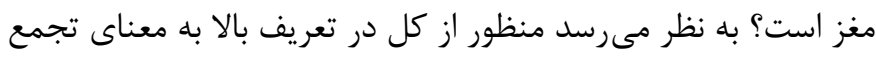
تمام ساختارهاى مغز نيست بلكه تعريفى كاركردى مد نظر است.

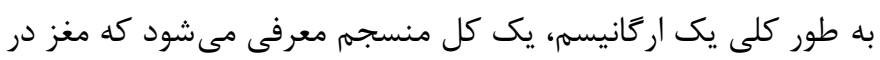

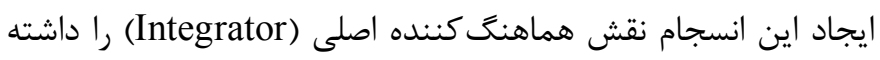

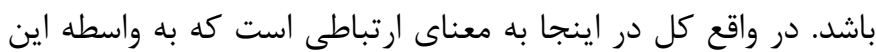

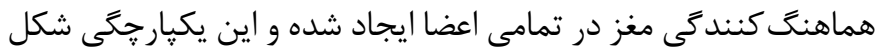
Inte-) مى يابد. در واقع كل در اينجا به معناى داراى كاركرد يكيار تهایه (grated function 
مركَ ساقه مغز: توقف غير قابل بازگشت كاركرد ساقه مغز در رويكرد مرى ساقه مغز، بيمارانى كه در دسته بيماران داراى حيات نباتى (Permanent vegetative state) قرار مى كيرند، يعنى ساقه دراته مغزى آنها فعال بوده و اعمالى نظير تِّ قلب، تنفس و خرخه خواب

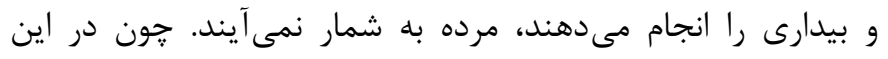

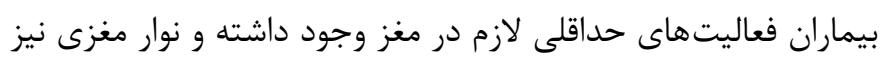

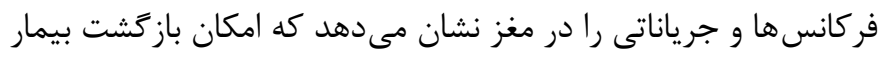

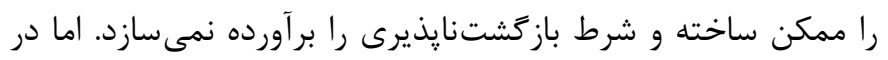
خصوص كماى بىبازگشت (Deep coma)، كه اولين بار در 1909 توسط نورولوزيست هاى فرانسوى Moulart و Galoun مطرح شد، با باري

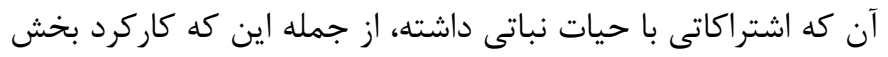

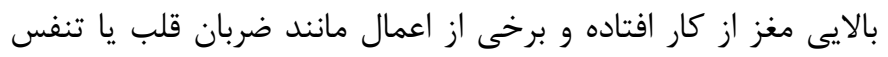

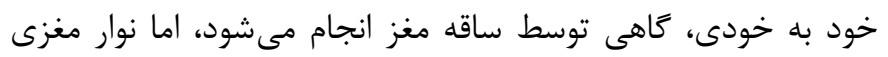

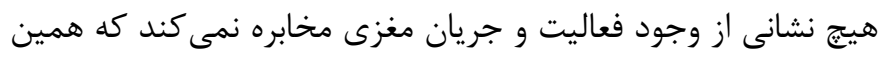

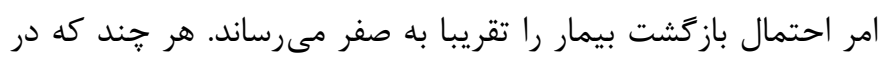

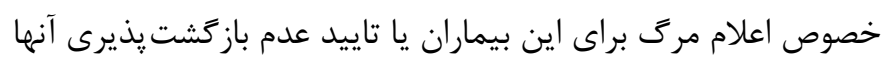
نيز، مخالفت هايى وجود دارد. Pallis از مدافعان بحث مرى ساقه مغز ميى نويسد: الساقه مغز ايستخاه جابه جايى براى همه ورودى ها و خروجى هاى دو نيمكره مغزى است.

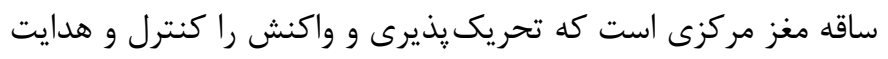

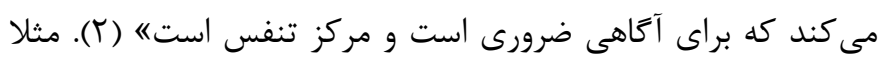

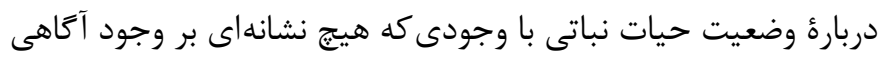

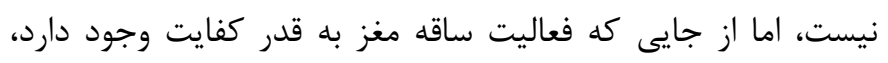

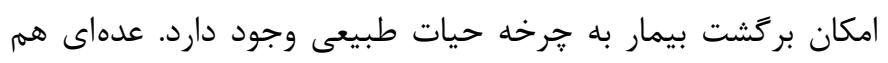

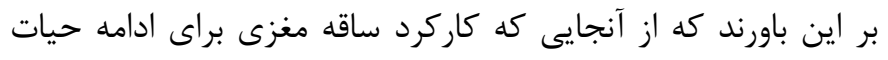

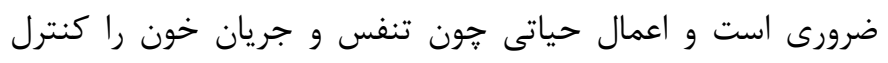

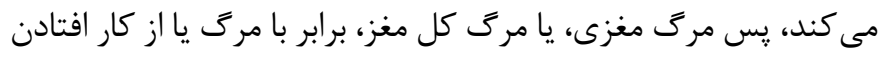

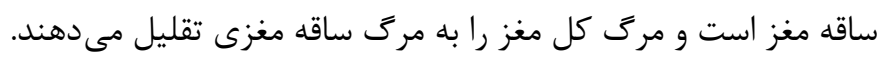

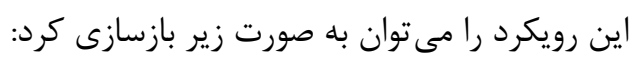

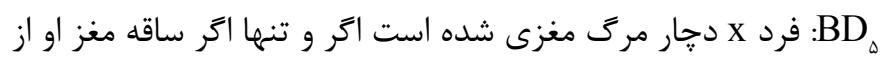
كار افتاده باشد اما اين رويكرد با مخالفت جدى گروهى مواجه شد كه بر آن باورند كه معيار

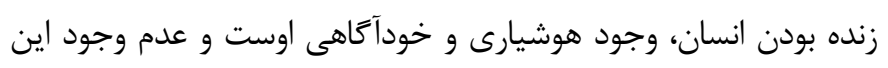

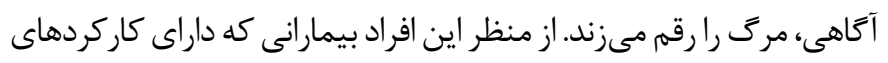

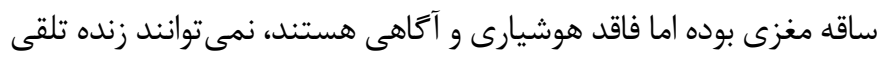

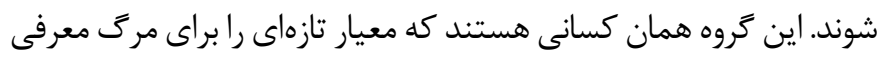

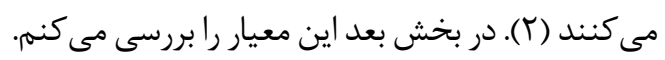

تعريف اركانيسميك از مرگ: از دست دادن برَشتنايذير عملكرد اركانيسم (به مثابه يك كل).

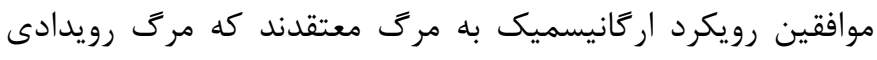

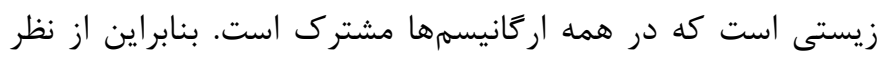

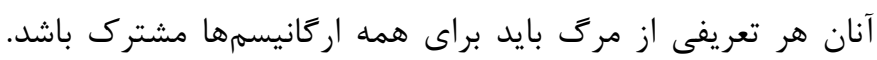

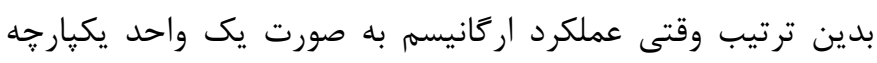

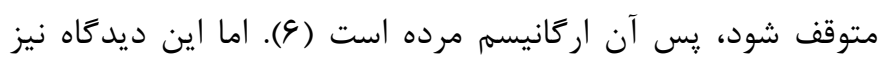

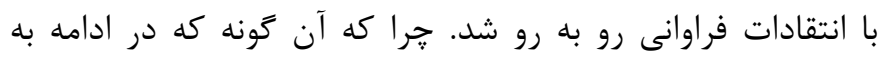

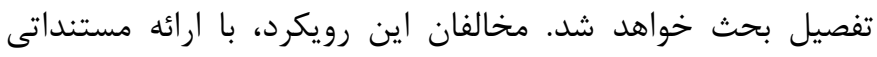

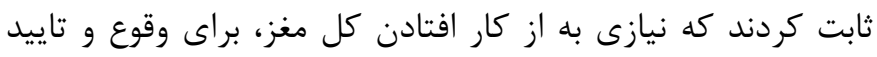

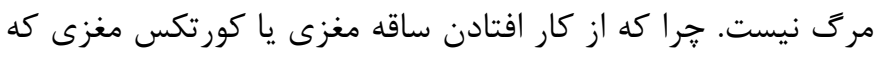

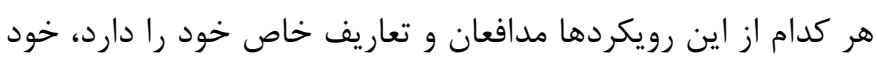

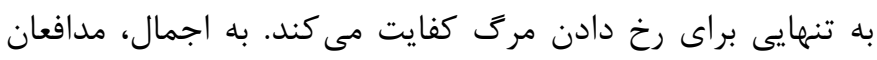

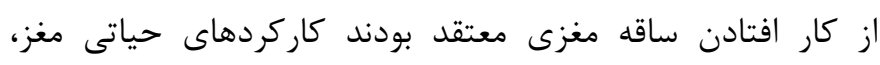

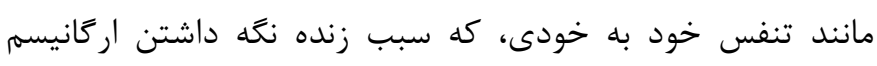

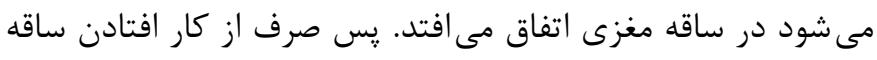

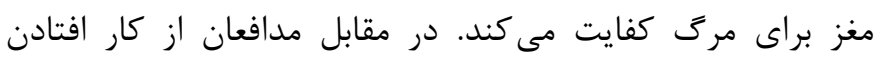

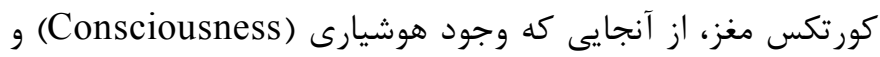

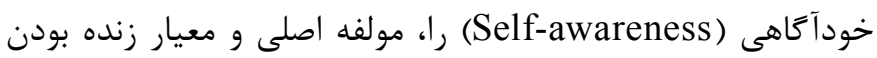

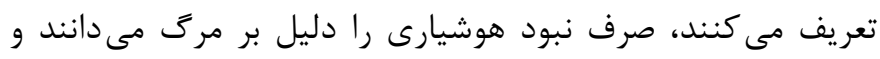

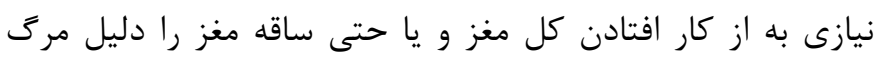

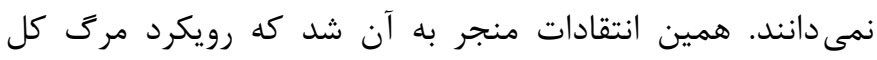

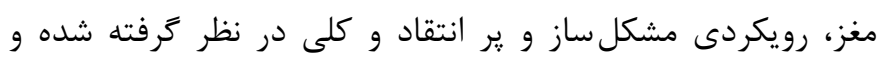

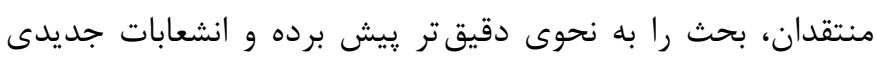

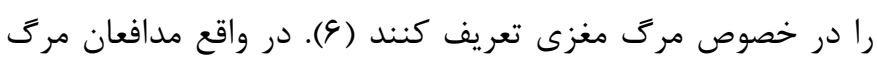

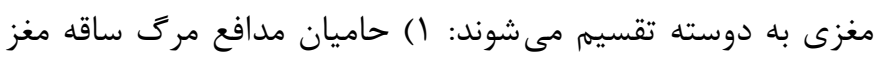

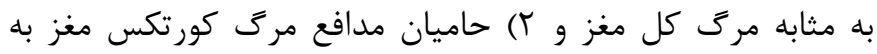

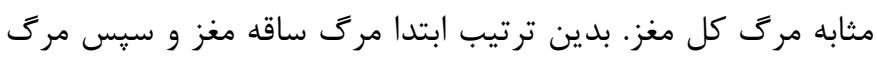
كورتكس مغز را بررسى مى كنيم.

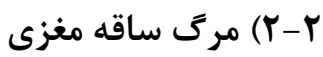

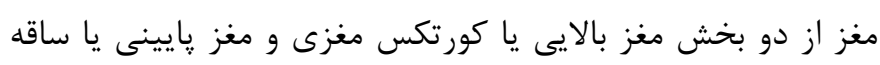

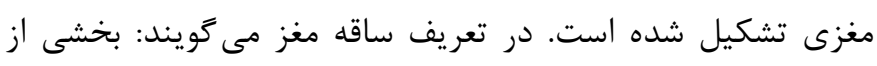

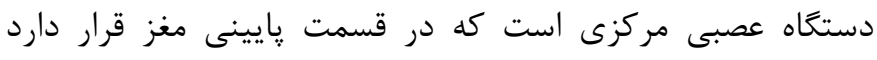

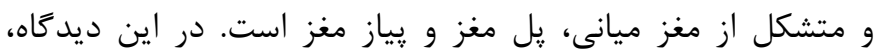

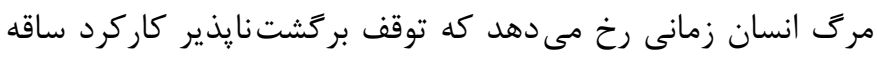
مغزى رخ دهد. 
با توجه به مفهوم كواليا، فيلسوفان ذهن معتقدند كه حالات ذهنى Conscious

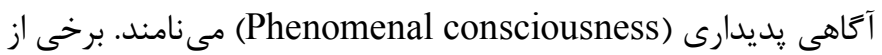

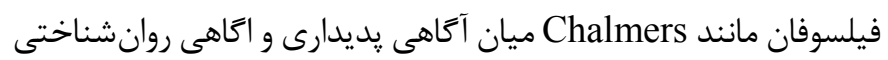

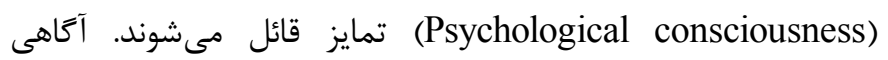
روانشناختى را مىتوان به صورت زير صورتبندى كرد:

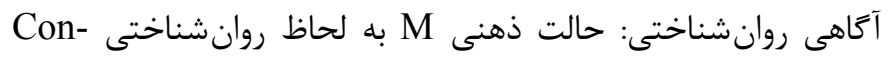

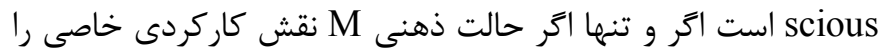
در تبيين رفتار انجام دهد. در واقع بودن در حالت ذهنى M به لحاظ روانشناختى دسترسى دهى به اطلاعاتى را فراهم مى كند كه براى كنترل رفتار فرد مستقيما

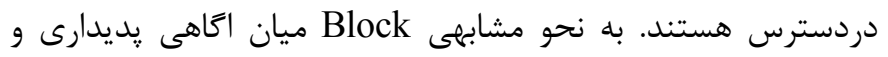
آكاهى در دسترس (Access consciousness) تمايز قائل مى شودن.

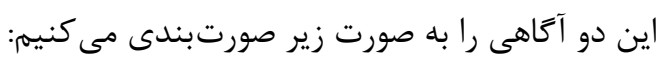

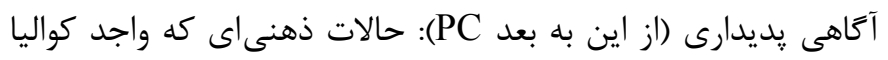

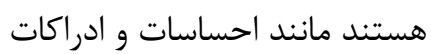
آكاهى در دسترس (از اين به بعد AC): حالت ذهنى M M يك وضعيت آنسات Access conscious مستقيم استدلالورزى (Reasoning)، كلام (Speech) و عمل آماده (Poise)

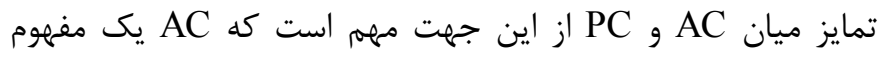

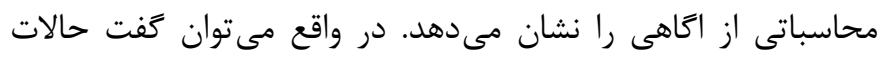

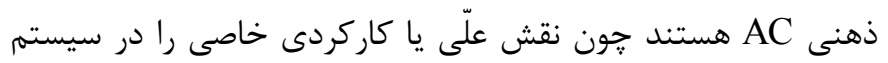
شناختى فرد بازى مى كنند.

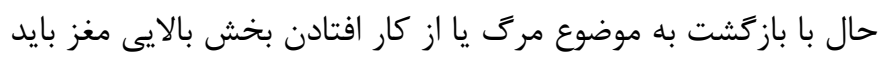
كَفت در اين رويكرد، مرگ انسان يعنى قطع غير قابل باز حَت توانايى براى داشتن آكاهى در دسترس و آكاهى يديدارى. اين تعريف را به صورت زير صورتبندى مى كنيه.

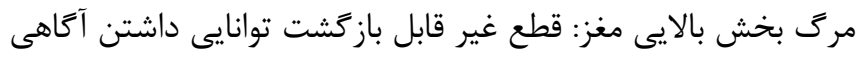

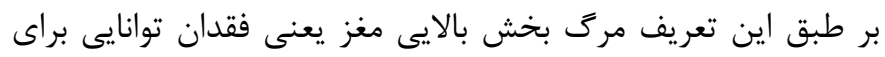

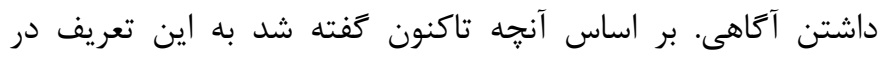

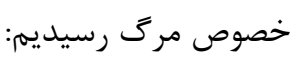

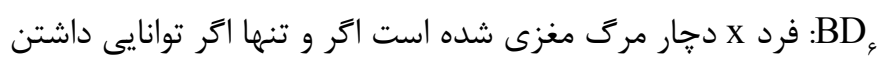

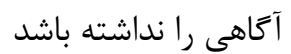
توانايى يا ظرفيت، در اين تعريف به معناى آن است افرادى كه ساختار عصبشناختى سالم دارند و ظرفيت بازگشتيذيرى و احيا سلامت دان در آنها وجود دارد، مرده به شمار نمى آيند. روش تشخيص اين نوع آنارت r-righer brain death) مرك كور تكس يا بخش بالايى مغز بحث برانگيزترين معيار كه همانا محل بحث ما نيز درباره مرى

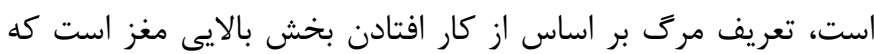

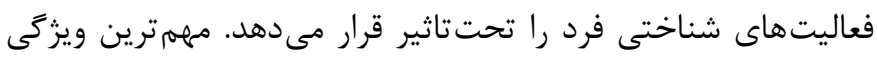
در فعاليت هاى شناختى آكاهى و هوشيارى انسانى را مبنا قرار مى دهى دهد.

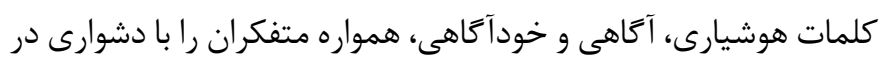

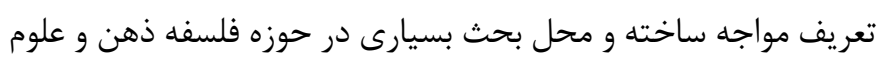

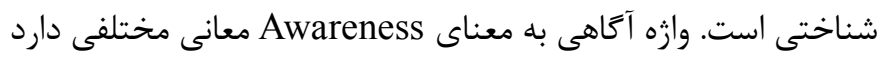
برخى اوقات اين وازه براى توصيف يديده توجه كردن به يك شى در الهر فضاى ادراكى فرد به كار مى رود. گاهى اين وازه براى توصيف هوشيارى يا شناخت فرد از يك وضعيت استفاده مى شود و كاهى نيز براى هوشيار

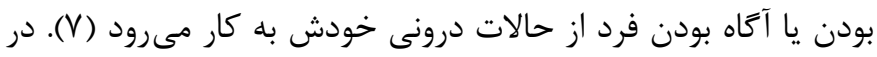

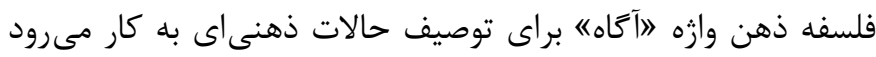

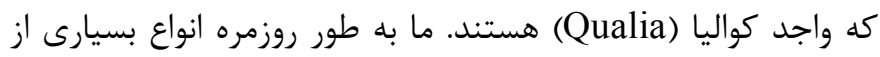
احساسات و تجربهها را از سر مى كذرانيم؛ از ادراكات كرفته تا احساسات بدنى و عواطف. براى مثال، من شىء قرمزى را مىبينم (ادراك ديدارى)،

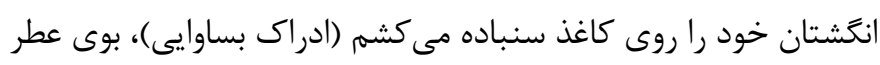

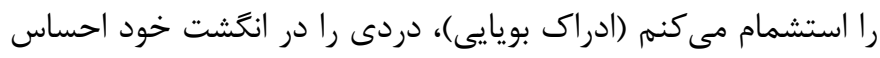
مى كنم (احساس بدنى)، و احساس خشم مى كنم (عاطفه). در هر يك از

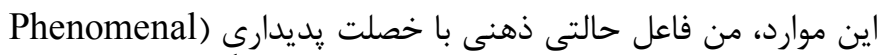

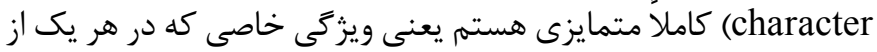
تجربهيهاى من نمودار مىشود؛ در مورد نخست، خصلت يديدارى تجربه

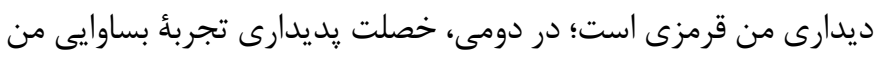

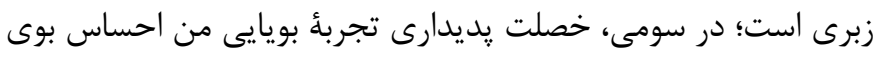

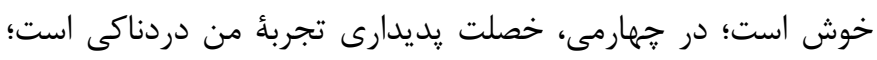

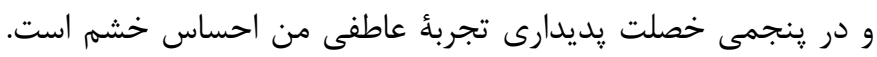

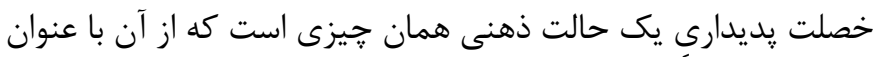
كيفيت (What it is like) يا حس و حال از سركذراندن آن حالت براى من، نام برده مىشود. فيلسوفان گاهى اين قبيل خصلتهاى يديدارى

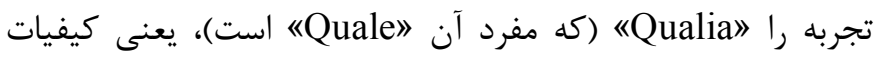

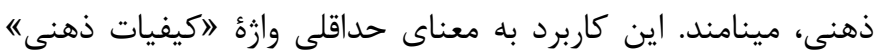

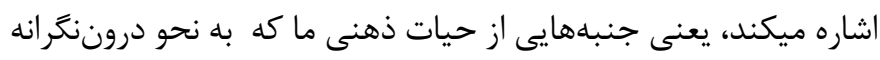
و و يديدارى (Introspective)

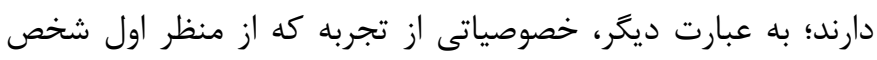

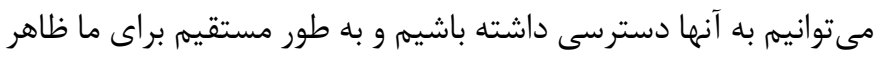
مىشوند، مانند ويزگى قرمزى يا بوى خوش كه در تجربه هاى ديدارى يا بويايى ما، به طور يديدارى و مستقيمى براى ما ظاهر مىشوند. حال 
براى داشتن آكاهى محصول ويزَّى ايى هست كه از دست دادن آن بان

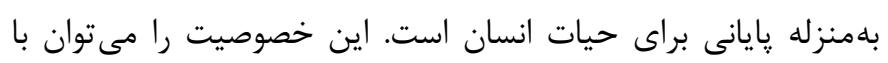

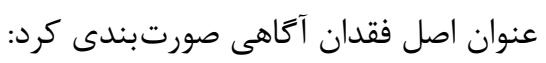

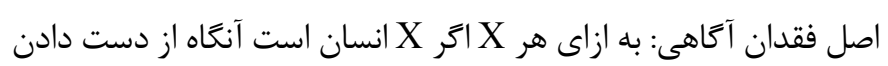

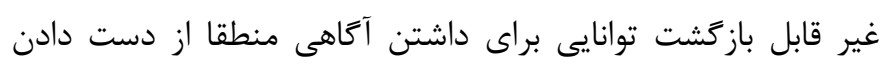

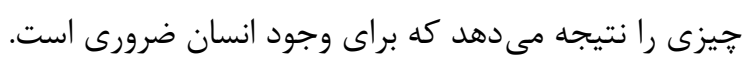

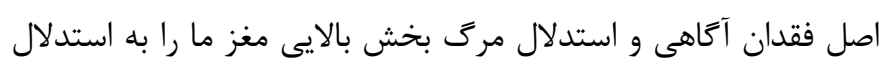

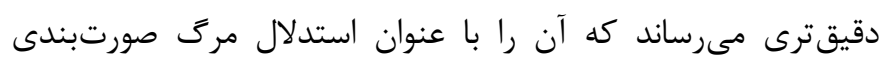

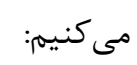

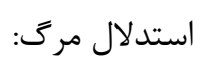

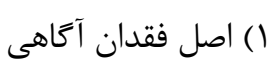

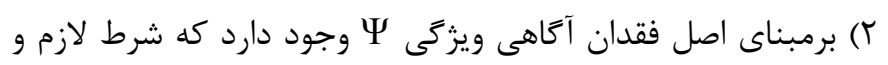

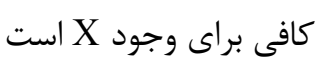

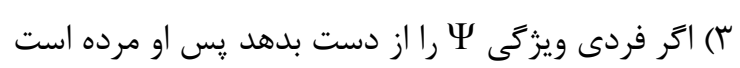

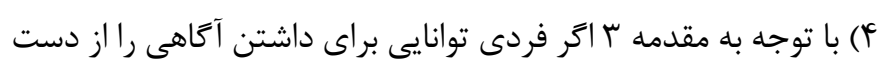

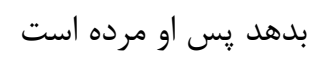

\section{نتيجه كيرى} از آن جه كَفته شد اين كَونه مىتوان نتيجه كَرفت كه ديدكاه مركى

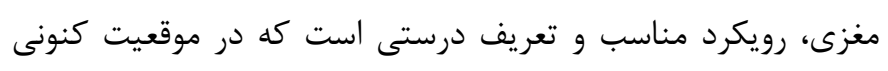

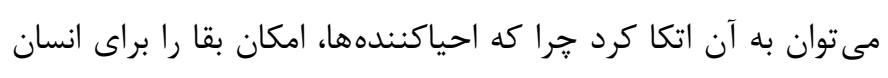

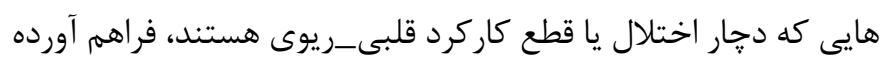

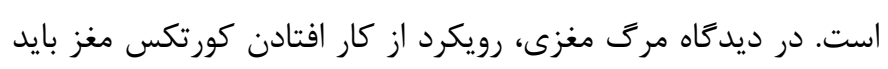

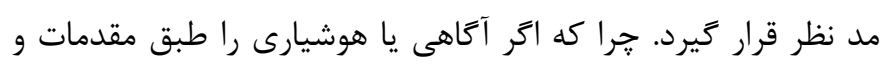

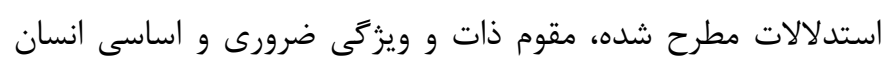

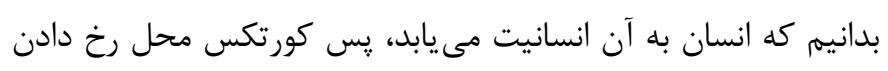

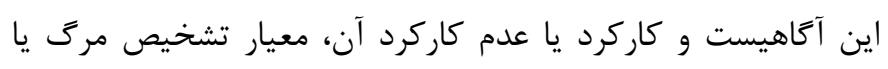

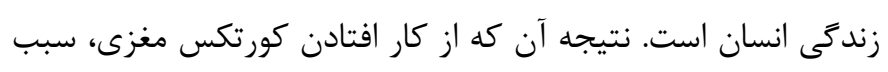

$$
\text { قطع آكاهى و مركَ مى نشود. }
$$

تشكر و قدرداذى

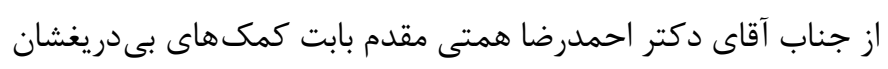

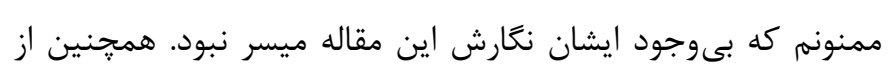

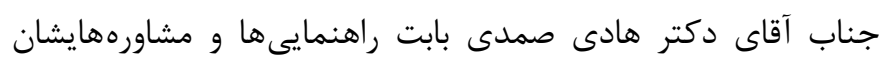

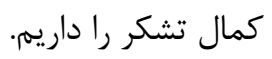

مركى هم آزمونهايى است كه سلامت يا عدم سلامت اين ساختارها

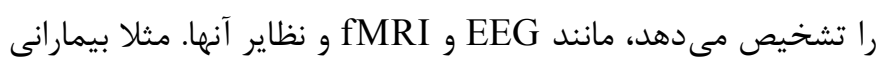

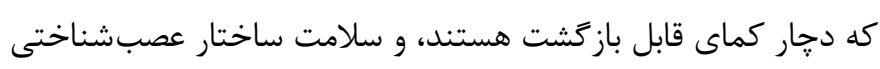

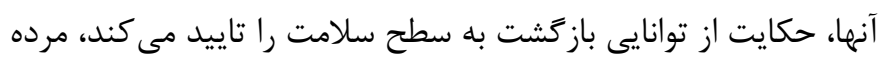

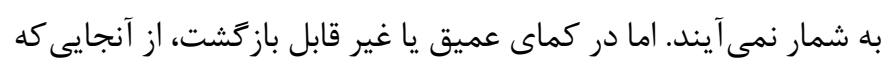

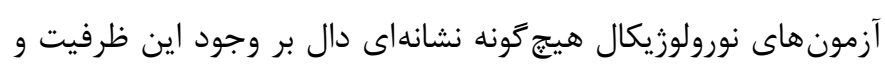

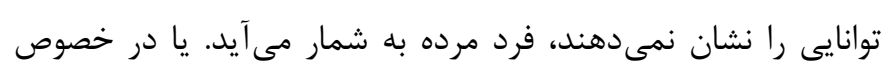

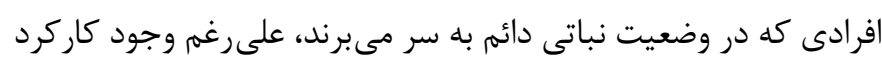

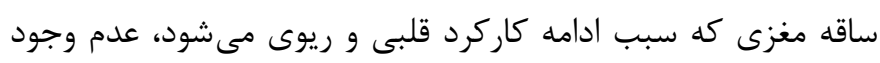

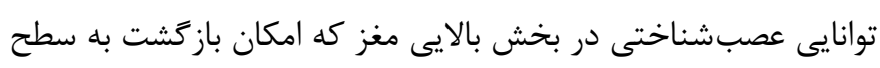

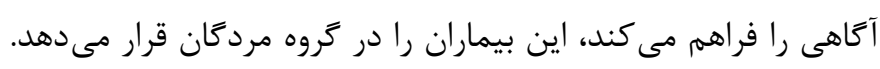

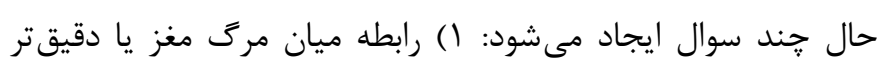

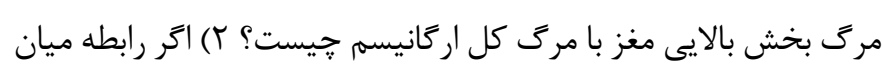

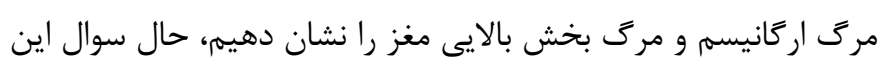

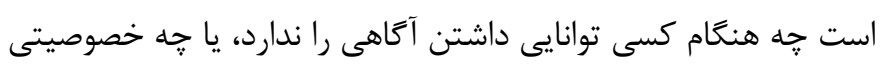

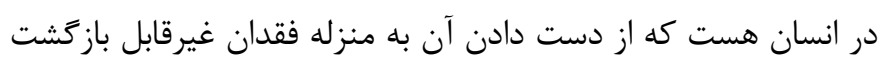

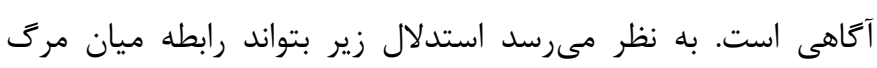

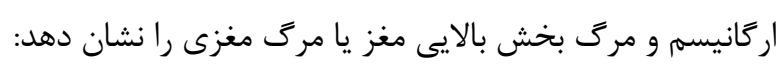

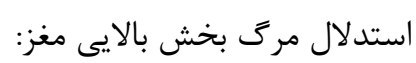

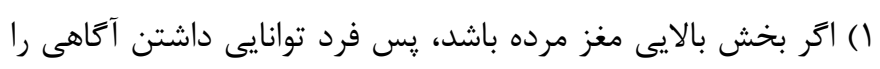
ندارد

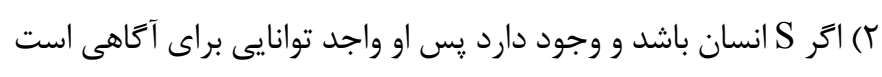

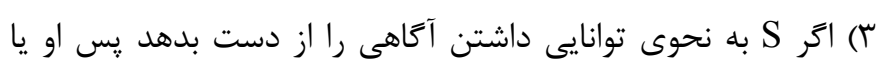

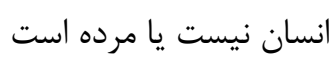

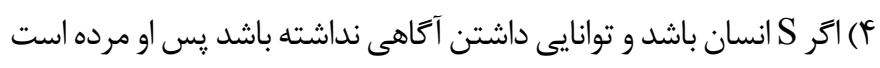

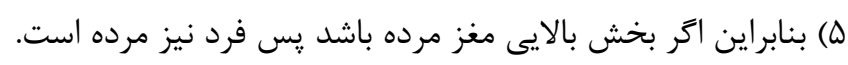

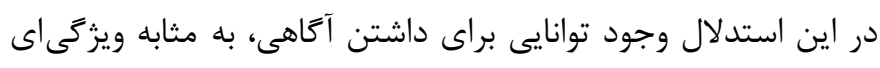

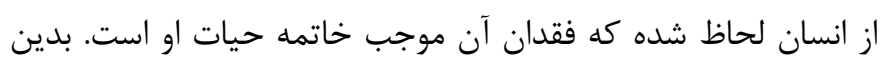

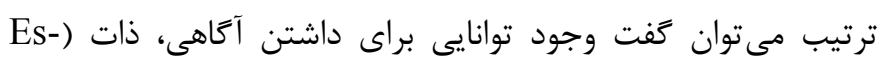
ذات دence

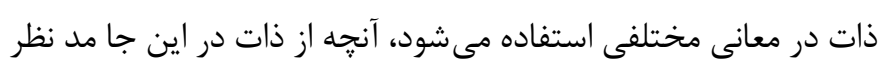

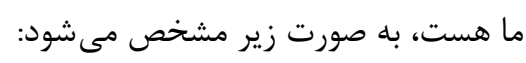

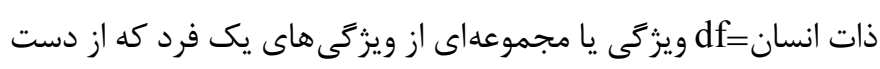

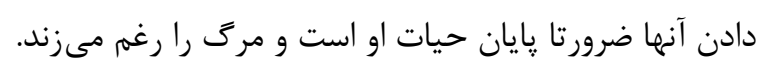

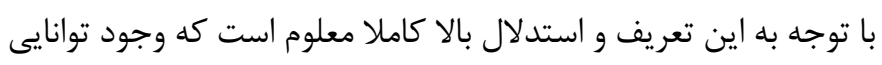




\section{References}

1. DeGrazia. Human identity and bioethics. Cambridge:Cambridge University Press;2005.

2. Laureys S. Death, unconsciousness and the brain. Nature Reviews Neuroscience. 2005;6(11):899-909.

3. Shewmon M. The brain and somatic integration: Insights into the standard Biological rationale for equating brain death with death. Journal of Medicine and Philosophy. 2001;26(5):457-478.
4. Bernat JL. Contemporary controversies in the definition of death. Progress in Brain Research. 2009;177:21-31.

5. Hershenov D. The problematic role of 'irreversibility' in the definition of death. Bioethics. 2003;17(1):89-100.

6. Zaner RM. Death: Beyond whole-brain criteria. Berlin:Kluwer Academic Publishers;1988.

7. Baker LR. Persons and bodies: A constitution view. Cambridge:Cambridge University Press;2000. 